Correction to: Effect of PEEP decremental on respiratory mechanics, gas exchange, pulmonary regional ventilation, and hemodynamics in patients with SARS-Cov-2-associated Acute Respiratory Distress Syndrome

Vincent Bonny ${ }^{1 *}$, Vincent Janiak ${ }^{2,3}$, Savino Spadaro ${ }^{4,5}$, Andrea Pinna ${ }^{2}$, Alexandre Demoule ${ }^{1,6}$ and Martin Dres 1,6

\begin{abstract}
Correction to: Critical Care (2020) 24:596 https://doi.org/10.1186/s13054-020-03311-9

Following publication of the original article [1], the authors reported a title error in addition gas exchange was written incorrectly throughout the article, the affiliations of the author group were incorrect, Table 1 was missing punctuation, and the table had alignment errors. The revised title, Table 1, and revised text are indicated hereafter, and the changes have been highlighted in bold typeface.
\end{abstract}

The incorrect title is:

Effect of PEEP decremental on respiratory mechanics, gasses exchanges, pulmonary regional ventilation, and hemodynamics in patients with SARS-Cov-2-associated acute respiratory distress syndrome

The original article can be found online at https://doi.org/10.1186/s1305 4-020-03311-9.

*Correspondence: v.bonny@hotmail.fr

1 Sorbonne Université, INSERM, UMRS1158 Neurophysiologie Respiratoire Expérimentale et Clinique, Paris, France

Full list of author information is available at the end of the article
The correct title is:

Effect of PEEP decremental on respiratory mechanics, gas exchange, pulmonary regional ventilation, and hemodynamics in patients with SARS-Cov-2-associated Acute Respiratory Distress Syndrome

The incorrect author group with affiliations read:

Vincent Bonny ${ }^{1,2 *}$, Vincent Janiak ${ }^{3,4}$, Savino Spadaro ${ }^{5,6}$, Andrea Pinna ${ }^{3}$, Alexandre Demoule ${ }^{1,2,7}$ and Martin Dres $^{1,2,7}$

1 Neurophysiologie respiratoire expérimentale et clinique, UMRS1158, INSERM, Sorbonne Université, Paris, France.

2 Service de Pneumologie, Médecine intensive Réanimation, Groupe Hospitalier Pitié-Salpêtrière, 47-83 boulevard de l'Hôpital, 75651 Paris Cedex 13, France.

3 LIMICS, UMR_S, UPMC Univ Paris 06, INSERM, Sorbonne Paris Cité, Université Paris 13, Sorbonne Universités, 1142 Paris, France.

4 Bioserenity, Paris, France. original author(s) and the source, provide a link to the Creative Commons licence, and indicate if changes were made. The images or other third party material in this article are included in the article's Creative Commons licence, unless indicated otherwise in a credit line to the material. If material is not included in the article's Creative Commons licence and your intended use is not permitted by statutory regulation or exceeds the permitted use, you will need to obtain permission directly from the copyright holder. To view a copy of this licence, visit http://creativecommons.org/licenses/by/4.0/. The Creative Commons Public Domain Dedication waiver (http://creativeco mmons.org/publicdomain/zero/1.0/) applies to the data made available in this article, unless otherwise stated in a credit line to the data. 
5 Department of Morphology, Surgery and Experimental Medicine, University of Ferrara, Ferrara, Italy.

6 Anaesthesia and Intensive Care Unit, Sant'Anna Hospital, Aldo Moro, Ferrara, Italy.

7 Médecine Intensive-Réanimation (Département "R3S"), Service de Pneumologie, AP-HP, Hôpital PitiéSalpêtrière, Sorbonne Université, F-75013 Paris, France.

The correct author group with affiliations should read:

Vincent Bonny ${ }^{1 *}$, Vincent Janiak ${ }^{2,3}$, Savino Spadaro ${ }^{4,5}$, Andrea Pinna ${ }^{2}$, Alexandre Demoule ${ }^{1,6}$ and Martin Dres ${ }^{1,6}$

1 Sorbonne Université, INSERM, UMRS1158 Neurophysiologie respiratoire expérimentale et clinique, Paris, France

2 Sorbonne Université, UPMC Univ Paris 06, INSERM, Sorbonne Paris Cité, Université Paris 13, LIMICS, UMR_S 1142, Paris, France

3 Bioserenity, 20 rue Berbier-du-Mets, 75013, Paris, France

4. Department of Morphology, Surgery and Experimental Medicine, University of Ferrara, Italy

5 Anaesthesia and Intensive Care Unit, Sant'Anna Hospital, Aldo Moro, Ferrara. Italy

6 AP-HP. Sorbonne Université, Hôpital Pitié-Salpêtrière, Service de Pneumologie, Médecine intensive - Réanimation (Département "R3S"), 75013, Paris, France

The sentence currently reads:

PEEP decremental was not associated with significant changes in gasses exchanges but was associated with a significant decrease in plateau pressure and driving pressure and with a significant decrease in end-inspiratory and in end-expiratory transpulmonary pressures.

The sentence should read:

PEEP decremental was not associated with significant changes in gas exchange but was associated with a significant decrease in plateau pressure and driving pressure and with a significant decrease in end-inspiratory and in end-expiratory transpulmonary pressures.
The sentence currently reads:

These findings suggest that mechanically ventilated SARS-Cov-2 patients have a relatively preserved lung compliance and that the use of high PEEP was associated with a decrease in lung compliance while providing no beneficial effect on gasses exchanges.

The sentence should read:

These findings suggest that mechanically ventilated SARS-Cov-2 patients have a relatively preserved lung compliance and that the use of high PEEP was associated with a decrease in lung compliance while providing no beneficial effect on gas exchange.

Table 1 caption currently reads:

Table 1 Changes in hemodynamics, gasses exchanges, respiratory mechanics, and pulmonary regional ventilation between high and low PEEP in supine $(n=10)$

Table 1 caption should read:

Table 1 Changes in hemodynamics, gas exchange, respiratory mechanics, and pulmonary regional ventilation between high and low PEEP in supine $(n=10)$

The sentence currently reads:

In conclusion, this series of SARS-Cov-2-related ARDS describe an individualized multimodal approach of lung mechanics, gasses exchanges, pulmonary regional ventilation, and hemodynamics at the early phase of the disease and suggest that low PEEP should be used as part of the ventilation strategy, rather than high PEEP.

The sentence should read:

In conclusion, this series of SARS-Cov-2-related ARDS describe an individualized multimodal approach of lung mechanics, gas exchange, pulmonary regional ventilation, and hemodynamics at the early phase of the disease and suggest that low PEEP should be used as part of the ventilation strategy, rather than high PEEP.

Table 1 should read: 
Table 1 Changes in hemodynamics, gas exchange, respiratory mechanics and pulmonary regional ventilation between High and Low PEEP in supine $(n=10)$

\begin{tabular}{|c|c|c|c|}
\hline & High PEEP & Low PEEP & $P$ \\
\hline \multicolumn{4}{|l|}{ Clinical variables } \\
\hline Heart rate, beats.min ${ }^{-1}$ & 72 [64-95] & $76[59-97]$ & 0.977 \\
\hline Systolic arterial blood pressure, $\mathrm{mmHg}$ & 125 [108-138] & $129[118-140]$ & 0.555 \\
\hline Diastolic arterial blood pressure, $\mathrm{mmHg}$ & 63 [49-69] & $58[48-65]$ & 0.158 \\
\hline Mean arterial blood pressure, $\mathrm{mmHg}$ & 77 [72-89] & 77 [73-86] & $>0.999$ \\
\hline \multicolumn{4}{|l|}{ Transpulmonary thermodilution indices } \\
\hline Cardiac index, L. $\min ^{-1} \cdot \mathrm{m}^{-2}$ & $2.5[2.0-3.0]$ & $2.6[2.2-3.3]$ & 0.027 \\
\hline Global end-diastolic volume indexed, $\mathrm{mL} . \mathrm{m}^{-2}$ & $661[551-870]$ & $668[559-813]$ & 0.432 \\
\hline Extravascular lung water, $\mathrm{mL} . \mathrm{kg}^{-1}$ & $15[13-18]$ & $14[13-17]$ & 0.551 \\
\hline Pulmonary vascular permeability index & $3.3[2.7-3.9]$ & $3.3[2.7-3.6]$ & 0.607 \\
\hline Cardiac function index, $\mathrm{min}^{-1}$ & $4.4[2.4-5.3]$ & $4.5[2.8-5.8]$ & 0.008 \\
\hline \multicolumn{4}{|l|}{ Gas exchanges } \\
\hline $\mathrm{pH}$ & $7.35[7.29-7.37]$ & $7.35[7.30-7.41]$ & 0.305 \\
\hline $\mathrm{PaCO}_{2}, \mathrm{mmHg}$ & $45[39-51]$ & $44[40-47]$ & 0.191 \\
\hline $\mathrm{PaO}_{2} / \mathrm{FiO}_{2}$ ratio, $\mathrm{mmHg}$ & 116 [99-196] & $106[86-129]$ & 0.127 \\
\hline $\mathrm{SaO}_{2}, \%$ & 97 [95-98] & 96 [92-97] & 0.172 \\
\hline$V_{\mathrm{D}} / V_{\mathrm{T}}$ & $0.34[0.29-0.39]$ & $0.35[0.30-0.39]$ & 0.348 \\
\hline A-a gradient, mmHg & 374 [304-533] & $384[275-543]$ & 0.139 \\
\hline \multicolumn{4}{|l|}{ Respiratory mechanics } \\
\hline Respiratory rate, breaths. $\mathrm{min}^{-1}$ & $27[23-30]$ & $27[23-30]$ & - \\
\hline Tidal volume, $\mathrm{mL} . \mathrm{kg}^{-1} \mathrm{IBW}$ & $6.0[6.0-6.3]$ & $6.0[6.0-6.3]$ & - \\
\hline Positive end-expiratory pressure, $\mathrm{CmH}_{2} \mathrm{O}$ & $16[16-16]$ & $8[8-8]$ & 0.016 \\
\hline Peak pressure, $\mathrm{CmH}_{2} \mathrm{O}$ & $44[42-47]$ & $35[33-36]$ & 0.002 \\
\hline Plateau pressure, $\mathrm{CmH}_{2} \mathrm{O}$ & $28[27-31]$ & $20[18-21]$ & 0.002 \\
\hline Driving pressure, $\mathrm{CmH}_{2} \mathrm{O}$ & $14[11-16]$ & $12[10-13]$ & 0.004 \\
\hline End-expiratory transpulmonary pressure, $\mathrm{cmH}_{2} \mathrm{O}$ & $6[4-8]$ & $2[-1-4]$ & 0.002 \\
\hline End-inspiratory transpulmonary pressure, $\mathrm{cmH}_{2} \mathrm{O}$ & $14[13-17]$ & $9[6-10]$ & 0.002 \\
\hline Respiratory system compliance, $\mathrm{ml} \cdot \mathrm{cmH}_{2} \mathrm{O}^{-1}$ & $29[27-36]$ & $34[30-42]$ & 0.012 \\
\hline Respiratory system resistance, $\mathrm{cmH}_{2} \mathrm{O} \cdot \mathrm{L}^{-1} \cdot \mathrm{sec}^{-1}$ & $0.24[0.20-0.25]$ & $0.23[0.22-0.26]$ & $>0.999$ \\
\hline Lung compliance, $\mathrm{ml} \cdot \mathrm{cmH}_{2} \mathrm{O}^{-1}$ & $47[40-56]$ & $64[46-82]$ & 0.008 \\
\hline $\mathrm{R} / \mathrm{I}$ ratio & $0.33[0.21-0.54]$ & & - \\
\hline End-expiratory lung volume, $\mathrm{mL}$ & $2546[2151-3019]$ & 1725 [1450-2023] & 0.002 \\
\hline \multicolumn{4}{|l|}{ Electrical impedance tomography derived indices } \\
\hline Dorsal fraction, \% & $46[43-54]$ & 35 [32-39] & 0.002 \\
\hline Global inhomogeneity index, \% & $58[52-60]$ & $60[55-66]$ & 0.059 \\
\hline End-expiratory lung impedance & $251[179-404]$ & $139[83-243]$ & 0.008 \\
\hline Changes in end-expiratory lung impedance, \% & -118 [- 150 to -32$]$ & & 0.004 \\
\hline
\end{tabular}

Data are presented as median [interquartile range] or number (percentage). Wilcoxon matched-pairs signed-rank test was used to evaluate differences between the median values of paired data. $\mathrm{PaCO} 2$ partial pressure of arterial carbon dioxide, $\mathrm{PaO} 2$ partial pressure of oxygen, $\mathrm{FiO} 2$ fraction of inspired oxygen, $\mathrm{SaO}$, oxygen saturation, $V_{D} V_{T}$ estimated dead space fraction, $A$-a gradient alveolar-arterial gradient, $R / /$ recruitment to inflation ratio. $P$ values refer to the comparison between high and low PEEP for each patient

The Acknowledgments section currently reads:

Not applicable.

The Acknowledgments section should read:
We thank Umar Saleem for his contribution to this work.

All the changes requested are implemented in this correction, and the original article [1] has been corrected. 


\section{Author details}

${ }^{1}$ Sorbonne Université, INSERM, UMRS1158 Neurophysiologie Respiratoire Expérimentale et Clinique, Paris, France. ${ }^{2}$ Sorbonne Université, UPMC Univ Paris 06, INSERM, Sorbonne Paris CitéUniversité Paris 13, LIMICS, UMR_S 1142, Paris, France. ${ }^{3}$ Bioserenity, 20 rue Berbier-du-Mets, 75013 Paris, France. ${ }^{4}$ Department of Morphology, Surgery and Experimental Medicine, University of Ferrara, Ferrara, Italy. ${ }^{5}$ Anaesthesia and Intensive Care Unit, Sant'Anna Hospital, Aldo Moro, Ferrara, Italy. ${ }^{6}$ AP-HP. Sorbonne Université, Hôpital Pitié-Salpêtrière, Service de Pneumologie, Médecine intensive - Réanimation (Département "R3S"), 75013 Paris, France.

Published online: 04 December 2020

\section{Reference}

1. Bonny $V$, Janiak $V$, Spadaro $S$, et al. Effect of PEEP decremental on respiratory mechanics, gasses exchanges, pulmonary regional ventilation, and hemodynamics in patients with SARS-Cov-2-associated acute respiratory distress syndrome. Crit Care. 2020;24:596. https://doi.org/10.1186/s1305 4-020-03311-9.

\section{Publisher's Note}

Springer Nature remains neutral with regard to jurisdictional claims in published maps and institutional affiliations.
Ready to submit your research? Choose BMC and benefit from:

- fast, convenient online submission

- thorough peer review by experienced researchers in your field

- rapid publication on acceptance

- support for research data, including large and complex data types

- gold Open Access which fosters wider collaboration and increased citations

- maximum visibility for your research: over $100 \mathrm{M}$ website views per year

At BMC, research is always in progress.

Learn more biomedcentral.com/submissions 